\title{
Prognostic value of ACE I/D, AT1R A1166C, PAI-I 4G/5G and GPIIIa a1/a2 polymorphisms in myocardial infarction
}

\author{
Efrén Martínez-Quintana ${ }^{1}$, Ricardo Chirino ${ }^{2}$, Vicente Nieto-Lago ${ }^{1}$, \\ Patricia Pérez-Jiménez ${ }^{2}$, Laura López-Ríos ${ }^{2}$, Fayna Rodríguez-González ${ }^{3}$ \\ ${ }^{1}$ Cardiology Service, Insular-Materno Infantil University Hospital, Las Palmas de Gran Canaria, Spain \\ ${ }^{2}$ Department of Chemistry, Molecular Biology and Physiology, \\ Las Palmas de Gran Canaria University, Las Palmas de Gran Canaria, Spain \\ ${ }^{3}$ Dr. Negrín University Hospital, Las Palmas de Gran Canaria, Spain
}

\begin{abstract}
Background: Coronary artery disease (CAD) has turned into a prevalent cause of morbi-mortality contributing some polymorphisms in the recurrence of major adverse cardiac events (MACE).

Methods: Three hundred and fifty six patients with first myocardial infarction (MI) were followed up during a 60-month period to find out if ACE I/D, AT1R A1166C, PAI-I 4G/5G and GPIIIa a1/a2 polymorphisms, in combination with other classical cardiovascular risk factors, can contribute to the relapse of MACE.
\end{abstract}

Results: Two hundred and eighty five (80.1\%) men and 71 (19.9\%) women were followed up after first MI. The primary clinical endpoint, a composite of MACE, was reached in 106 (29.8\%) patients. In the Cox univariate survival analysis those risk factors influencing a poorer prognosis were age $(p=0.004)$, a positive family history of $C A D(p=0.007)$, diabetes $(p=0.004)$, smoking $(p=0.024)$, fibrinolytic therapy $(p=0.012)$ and having 2 or 3 vessels $C A D(p=0.046)$. Cox proportional hazards regression model showed that patients with the $D D$ genotype had a 1.5 increased risk of having an unfavorable outcome when compared with No-DD genotype patients (RR 1.561, 95\% CI 1.048-2.326, $p=0.028$ ) and that patients with the ACE DD genotype plus the AT1R No-AA genotype, the GPIIIa No-a1a1 genotype or a combination of both, had a twice higher risk than any other genotype of MACE in the follow-up (RR 1.978, 95\% CI 1.286-3.043, $p=0.002$ ).

Conclusions: Patients with the ACE DD genotype plus 1 or 2 unfavorable genotypes, the AT1R No-AA, the GPIIIa No-a1a1 or a combination of both, have twice higher the risk of MACE during their clinical follow-up. (Cardiol J 2014; 21, 3: 229-237)

Key words: ACE I/D, AT1R A1166C, PAI-I 4G/5G, GPIIIa a1/a2, polymorphisms, myocardial infarction

Address for correspondence: Efrén Martínez Quintana, MD, PhD, Servicio de Cardiología, Complejo Universitario Insular-Materno Infantil, Avenida Marítima del Sur s/s, 35016 Las Palmas de Gran Canaria, Spain, tel: 0034928441360, e-mail: efrencardio@gmail.com

Received: 26.04.2013 Accepted: 07.07.2013 


\section{Introduction}

Classical cardiovascular risk factors explain at most half of the cases of coronary events and therefore new factors are looked for in the area of the molecular genetics that may explain the difference. Within it, polymorphisms, which scarcely alter the function of the codified protein, seem to promote an atherogenic effect contributing to the development of coronary heart disease [1].

The potential role of this study is to examine the relationship between polymorphisms (angiotensin-I converting enzyme [ACE] I/D, angiotensin 1 receptor [AT1R] A1166C, plasminogen activator inhibitor-1 [PAI-I] 4G/5G and glycoprotein IIIa [GPIIIa] a1/a2), classical cardiovascular risk factors and coronary angiographic data in the recurrence of a major adverse cardiac event (MACE) after first myocardial infarction (MI).

\section{Methods}

Three hundred and fifty six surviving patients, admitted to the Cardiology Service of the Complejo Hospitalario Universitario Insular-Materno Infantil of Gran Canaria due to first MI, were prospectively followed up over a period of 60 months. The diagnosis of MI was performed according to the ACC/ /AHA guidelines for the management of patients with ST-elevation MI [2] and unstable angina/non ST-elevation MI [3]. Inclusion criterion was being older than 18 years old and exclusion criteria were having a systemic malignant disease, a terminal chronic illness or a previous MI, coronary artery bypass grafting or coronary angioplasty.

High blood pressure was defined as a repeatedly elevated systolic/diastolic blood pressure of 140/90 mm Hg or higher. Dyslipidemia was determined if total cholesterol concentration was above $240 \mathrm{mg} / \mathrm{dL}$ or the patient was under lipid-lowering treatment. Diabetes mellitus was defined as having a fasting plasma glucose level higher than $126 \mathrm{mg} / \mathrm{dL}$ or if the patient was under insulin or oral hypoglycemic treatment. Meanwhile, obesity was characterized if the body mass index (BMI) was above $30 \mathrm{~kg} / \mathrm{m}^{2}$. Left ventricle ejection fraction (LVEF) was calculated by echocardiography with the Teichholz formula and/or by endocardial tracing of the LV area, in systole and diastole, with the Simpson's EF method. Patients receiving fibrinolysis were treated with recombinant tissue plasminogen activator (rtPA). Patients were considered revascularized if they underwent percutaneous coronary intervention or coronary artery bypass surgery after the first MI. Coronary artery disease (CAD) was classified, by angiography, as non-significant if the lesion occupied less than $50 \%$ of the lumen of the coronary vessel, moderate if the lesion occupied $50-75 \%$ of the lumen of the coronary vessel and severe if it occupied more than $90 \%$ of the lumen. The lesion was considered diffuse when a long segment of the coronary artery was affected.

The primary clinical endpoint was the recurrence of MACE (acute MI, unstable angina, sudden cardiac death or ischemic heart failure) during a 60-month period of follow-up and the analysis was performed by citation, telephonic interview, review of medical records or death certificates. All the patients were Caucasian, and all of them gave informed consents to participate in the study. The protocol of the study was approved by the hospital's Ethics Committee.

\section{Polymorphisms and genetic analysis}

ACE gene plays an important role in the renin-angiotensin-aldosterone system (RAAS). The insertion deletion (I/D) polymorphism in this gene refers to an Alu repetitive sequence $287 \mathrm{bp}$ long, in intron 16 , resulting in three genotypes, DD and II homozygotes and ID heterozygotes. The $\mathrm{I} / \mathrm{D}$ polymorphism is reported to determine circulating and tissue ACE levels, so that individuals homozygous for the $\mathrm{D}$ allele have higher tissue and plasma ACE concentrations than heterozygotes and II homozygotes [4]. Therefore, patients with the ACE DD genotype are, theoretically, at an increased risk of $\mathrm{MI}$.

ACE I/D polymorphism: Genomic DNA was obtained from peripheral leucocytes $(300 \mu \mathrm{L}$ of whole blood) and the ACE I/D polymorphism was determined by polymerase chain reactions (PCR). PCR was performed with sense primer 5' CTG GAG ACC ACT CCC ATC CTT TCT 3' and antisense primer 5' GAT GTG GCC ATC ACA TTC GTC AGA 3' being he mutated oligonucleotide inserted into one of the two primers. The final volume of the mixture was $50 \mu \mathrm{L}$ and contained $0.76 \mu \mathrm{g}$ DNA, $50 \mathrm{mM} \mathrm{KCl}, 10 \mathrm{mM}$ Tris- $\mathrm{HCl}, \mathrm{pH}$ 8.3, $3 \mathrm{mM} \mathrm{MgCl} 2,0.5 \mathrm{mM}$ dNTPs, $20 \mathrm{pM}$ of each primer and $1 \mathrm{U}$ Taq polymerase. PCR cycle was $10 \mathrm{~min}$ of denaturation at $94^{\circ} \mathrm{C}, 30$ cycles of $1 \mathrm{~min}$ each at $94^{\circ} \mathrm{C}$ denaturation, $58^{\circ} \mathrm{C}$ annealing, $72^{\circ} \mathrm{C}$ extension and $7 \mathrm{~min}$ of final extension at $72^{\circ} \mathrm{C}$. The PCR products were separated on $2 \%$ agarose gel and visualized by ethidium bromide staining. The I allele produced a fragment in the 490-bp area and the $\mathrm{D}$ allele produced a fragment in the 190-bp area. The ID genotype showed 2 separate bands 
in the $490 \mathrm{bp}$ and in the $190 \mathrm{bp}$ areas. To avoid the possibility of mistyping the ID heterozygotes as DD homozygotes, all DD genotypes were re-amplified by using a second primer pair specific for the inserted sequence [5].

AT1R A1166C polymorphism can potentially lead to RAAS activation; when the $\mathrm{C}$ allele is present, AT1R density and sensitivity to angiotensin II increase. In fact, AT1R A1166C polymorphism, an adenine/cytosine base transversion at nucleotide position 1166, has been associated with ischemic heart disease and hypertension [6].

AT1R A1166C polymorphism: Genomic DNA was prepared from peripheral blood leukocytes and PCR. ATR1 A1166C polymorphism (a single base substitution from A1166 to C1166) was carried out in a total volume of $50 \mu \mathrm{L}$ containing genomic DNA, 15 pmol of each primer, $1 \mathrm{X}$ Taq polymerase buffer $\left(1.5 \mathrm{mmol} / \mathrm{L} \mathrm{MgCl}_{2}\right)$, and $1.2 \mathrm{U}$ of ampliTaq DNA polymerase (Perkin Elmer, Foster City, CA, USA). The primers for ATR1 gene were forward 5'-TTG AGG TTG AGT GAC ATG TTC GA-3' and backward 5'-CGG TTC AGT CCA CAT AAT GCA-3'. The PCR cycling conditions for $\mathrm{A} 1166 \mathrm{C}$ were set as: 1 cycle at $94^{\circ} \mathrm{C}$ for $3 \mathrm{~min}$, 30 cycles at $95^{\circ} \mathrm{C}$ for $30 \mathrm{~s}, 55^{\circ} \mathrm{C}$ for $30 \mathrm{~s}$, and $72^{\circ} \mathrm{C}$ for $60 \mathrm{~s}$, and 1 final cycle of extension at $72^{\circ} \mathrm{C}$ for $10 \mathrm{~min}$. The reaction was then incubated for $2 \mathrm{~h}$ at $37^{\circ} \mathrm{C}$, and then $10 \mu \mathrm{L}$ of the digested products were loaded into a $3 \%$ agarose gel with ethidium bromide staining and separated by electrophoresis. The A1166C polymorphism of ATR1 was categorized as divisible homozygotes (CC), indivisible homozygotes (AA), and heterozygotes (AC) [7].

The $4 \mathrm{G} / 5 \mathrm{G}$ I/D polymorphism (4 or 5 sequential guanosines, respectively) of PAI-1 is a major inhibitor of fibrinolysis. The polymorphism is located in the gene promoter region (chromosome 7) and results in allele-specific responses to multiple agents. Accordingly, studies have shown the $4 \mathrm{G}$ allele to be associated with both higher levels of PAI-1 and cardiovascular risk [8].

PAI-1 4G/5G polymorphism: Genomic DNA was obtained from peripheral blood and genotyping of the $4 \mathrm{G} / 5 \mathrm{G}$ polymorphism in the PAl-1 promoter region was performed by PCR using the following oligonucleotides: 5'-CACAGAGAGAGTCTGGCCACGT-3' (sense) and 5' CCAACAGAGGACTCTTGGTCT-3' (antisense). Reactions were performed in volumes of $50 \mu \mathrm{L}$ with $0.06 \mathrm{~mol}$ of each oligonucleotide, $1.2 \mathrm{U}$ of Taq DNA polymerase, $1.5 \mathrm{mmol}$ of $\mathrm{MgCl}_{2}$ and $0.1 \mathrm{mmol}$ of each dNTP. The reaction conditions were as follows: initial denaturation at $95^{\circ} \mathrm{C}$ for $3 \mathrm{~min}$ followed by 30 cycles of denaturation at $95^{\circ} \mathrm{C}$ for $30 \mathrm{~s}$, alignment at $60^{\circ} \mathrm{C}$ for $30 \mathrm{~s}$, and an extension step at $72^{\circ} \mathrm{C}$ for $30 \mathrm{~s}$, followed by a final linear extension step at $72^{\circ} \mathrm{C}$ for $1 \mathrm{~min}$. Amplification products of $99 \mathrm{bp}(5 \mathrm{G})$ and $98 \mathrm{bp}(4 \mathrm{G})$ were obtained. The DNA fragments were separated by electrophoresis in $4 \%$ agarose gels and visualized using ethidium bromide [9].

The A1/A2 polymorphism of GPIIIa gene, caused by a thymine to cytosine nucleotide substitution at position 1565 that is associated with the occurrence of the amino acid leucine to proline variant at residue 33 of the mature protein, has been widely studied in cardiovascular diseases showing that possession of an A2 allele increases the risk for $\mathrm{MI}$ and $\mathrm{CAD}$ [10].

GPIIIa a1/a2 polymorphism: Genomic DNA was obtained from peripheral leucocytes and PCR was used to detect the GPIIIa a1/a1 polymorphism using upstream primer 5'-TGGACTTCTCTTTGGGCTCCTGACTTAC-3' and the downstream primer 5'-CGATGGATTCTGGGCACAGTTATC-3'. DNA was amplified for 37 cycles of denaturation at $96^{\circ} \mathrm{C}$ for $45 \mathrm{~s}$, annealing at $57^{\circ} \mathrm{C}$ for $45 \mathrm{~s}$, and extension at $72^{\circ} \mathrm{C}$ for $60 \mathrm{~s}$. The final extension step was at $72^{\circ} \mathrm{C}$ for $4 \mathrm{~min}$. The $266 \mathrm{bp}-$ -product was then incubated at $37^{\circ} \mathrm{C}$ for $1 \mathrm{~h}$ with $10 \mathrm{U}$ of MspI. The resulting fragments were then separated by size in a $2 \%$ agarose gel and visualized by ethidium bromide staining [11].

\section{Statistical analysis}

Quantitative variables were expressed as mean \pm standard deviation or median and $5^{\text {th }}$ and $95^{\text {th }}(5 ; 95)$ percentiles to describe a distribution of data. Qualitative variables were expressed as percentages. Possible associations between categorical variables were evaluated using the Pearson $\chi^{2}$ test or Student's t test for continuous data. The nonparametric Mann-Whitney U test was used to compare two independent samples when the assumption of normality or homogeneity of variance was not met. The Bonferroni correction was applied for adjusting statistical results for multiple comparisons. Table 1 shows the polymorphisms' dichotomization with those favorable and unfavorable genotypes.

Kaplan-Meier survival curves were used to estimate time-to-event and the log-rank test was used to compare Kaplan-Meier survival curves. Meanwhile, Cox proportional hazards regression model was used to assess the effect of multiple covariates on survival. The results were expressed as odds ratios (ORs) with their $95 \%$ confidence 
Table 1. Dichotomization of the polymorphisms in unfavorable and favorable genotypes.

\begin{tabular}{|c|c|}
\hline Unfavorable genotypes & Favorable genotypes \\
\hline ACE DD & ACE II+ID \\
\hline $\begin{array}{l}\text { The DD genotype favors a higher production of ACE } \\
\qquad(50 \% \text { higher than the II) }\end{array}$ & Lower production of ACE \\
\hline Effect on endothelial proliferation and thrombosis & Smaller effect on endothelial proliferation and thrombosis \\
\hline AT1R AC+CC (No-AA) & AT1R AA \\
\hline Increased activity of the AT1R & Decreased activity of the AT1R \\
\hline $\begin{array}{l}\text { Greater effect on cell proliferation and } \\
\text { thrombosis caused by angiotensin II }\end{array}$ & $\begin{array}{l}\text { Smaller effect on cell proliferation and } \\
\text { thrombosis caused by angiotensin II }\end{array}$ \\
\hline PAI-I 4GG+4G5G (No 5G5G) & PAI-I 5G5G \\
\hline $\begin{array}{c}\text { The 4G4G has PAl concentrations } 10-50 \% \\
\text { higher than the } 5 \mathrm{G} 5 \mathrm{G}\end{array}$ & Lower PAl concentrations \\
\hline Increased thrombogenic risk & Low thrombogenic risk \\
\hline GPIIla No-a1a1 (a1a2+a2a2) & GPIIla a1a1 \\
\hline Increased activity of the GPIIb/IIla receptor & Decreased activity of the GPIIb/IIla receptor \\
\hline Increased platelet aggregation and thrombosis & Lower platelet aggregability \\
\hline
\end{tabular}

ACE — angiotensin-I converting enzyme; AT1R — angiotensin II type 1 receptor; PAI — plasminogen activator inhibitor; GPIIla — platelet glycoprotein Illa $[4,6,8,10]$

intervals (CIs). Data analysis was carried out using SPSS 18.0 (SPSS, Chicago, IL, USA).

\section{Results}

Over a period of $60(1 ; 188)$ months, $285(80.1 \%)$ men and 71 (19.9\%) women aged between 18 and 84 years old were followed up after hospital admission due to first MI. 181 (50.8\%) patients were less than 55 years old and $175(49.2 \%)$ patients were over 55 years old. $106(29.8 \%)$ patients had events during the follow-up. $65(18.3 \%)$ patients had unstable angina, $27(7.6 \%) \mathrm{MI}, 11(3.1 \%)$ sudden cardiac death, $3(0.8 \%)$ heart failure and 13 $(3.3 \%)$ patients death of non-cardiac origin. 237 $(66.6 \%)$ patients remained asymptomatic. Classical cardiovascular risk factors of the whole series and of the two subgroups of patients, patients with first MI below and above 55 years old, are summarized in Table 2. Meanwhile, genotype and alleles frequencies, in the overall sample, are indicated in Table 3. Infarction location, fibrinolytic treatment, LVEF and coronary angiographic data are shown in Table 4.

Pearson $\chi^{2}$ test evidenced no significant correlation between ACE I/D, AT1R A1166C, PAI-1 4G/5G and GPIIIa a1/a1 genotypic dichotomous variables and classical cardiovascular risk factors, even taken separately the early and late MI. The only polymorphism that reached statistical significance was the AT1R A1166C polymorphism, when compared with having or not having hypercholesterolemia, showing patients with dyslipidemia a higher incidence of AT1RAA genotypes $(p=0.017)$. Similarly, no association was seen between coronary angiographic data and the four studied polymorphisms.

Meanwhile, in the long-rank test, those classical cardiovascular risk factors that influenced a poorer outcome were age $(\mathrm{p}=0.004)$, having a family history of coronary heart disease $(\mathrm{p}=0.007)$, diabetes mellitus $(p=0.004)$, smoking $(p=0.024)$, being treated with fibrinolytic therapy $(\mathrm{p}=0.012)$ and having 2 or 3 vessels CAD ( $p=0.046)$. However, none of the studied polymorphisms influenced the prognosis in the univariate analysis.

Cox univariate analysis of the variables that influenced the clinical outcome and Cox proportional hazards regression model are shown in Tables 5 and 6 , respectively. Patients with the DD genotype had a 1.5 increased risk of having an unfavorable outcome when compared with No-DD patients (RR 1.561, 95\% CI 1.048-2.326, $\mathrm{p}=0.028$ ). Similarly, patients with DD genotype plus the AT1R No-AA genotype, the GPIIIa No-ala1 genotype or a combination of both, had twice more risk than any other genotype of presenting a MACE in the follow-up (RR 1.978, 95\% CI 1.286-3.043, $\mathrm{p}=0.002$ ).

\section{Discussion}

Atherosclerosis in general, and coronary heart disease in particular, has become a prevalent cause of 
Table 2. Demographics data of all the patients and of the subgroups below and above 50 years of age.

\begin{tabular}{|c|c|c|c|c|}
\hline Parameters & Total & AMI $<55$ years & AMI > 55 years & $\mathbf{P}$ \\
\hline Age & $55.6 \pm 13.2$ & $44.7 \pm 6.0$ & $66.9 \pm 7.9$ & 0.000 \\
\hline \multicolumn{5}{|l|}{ Gender: } \\
\hline Male & $285(80.9 \%)$ & $160(56.1 \%)$ & $125(43.8 \%)$ & \\
\hline Female & $71(19.1 \%)$ & $21(29.5 \%)$ & $50(70.4 \%)$ & 0.000 \\
\hline \multicolumn{5}{|l|}{ Family history: } \\
\hline No & $289(81.2 \%)$ & $142(78.5 \%)$ & $147(84.0 \%)$ & \\
\hline Yes & $67(18.8 \%)$ & $39(21.5 \%)$ & $28(16.0 \%)$ & 0.229 \\
\hline \multicolumn{5}{|l|}{ Diabetes mellitus: } \\
\hline No & $217(61.0 \%)$ & $126(69.6 \%)$ & $91(52.0 \%)$ & \\
\hline Yes & $139(39.0 \%)$ & $55(30.4 \%)$ & $84(48.0 \%)$ & 0.001 \\
\hline \multicolumn{5}{|c|}{ Arterial hypertension: } \\
\hline No & $178(50.0 \%)$ & $112(61.9 \%)$ & $66(37.7 \%)$ & \\
\hline Yes & $178(50.0 \%)$ & $69(38.1 \%)$ & $109(66.3 \%)$ & 0.000 \\
\hline \multicolumn{5}{|l|}{ Smoker: } \\
\hline No smoker & $114(32.0 \%)$ & $35(19.3 \%)$ & $79(45.1 \%)$ & \\
\hline Ex smoker & $79(22.2 \%)$ & $35(19.3 \%)$ & $44(25.1 \%)$ & \\
\hline Smoker & $163(45.8 \%)$ & $111(61.3 \%)$ & $52(29.7 \%)$ & 0.000 \\
\hline \multicolumn{5}{|l|}{ Dyslipidemia: } \\
\hline No & $105(29.5 \%)$ & $39(21.5 \%)$ & $66(37.7 \%)$ & \\
\hline Yes & $251(70.5 \%)$ & $142(78.5 \%)$ & $109(62.3 \%)$ & 0.001 \\
\hline \multicolumn{5}{|l|}{ Obesity: } \\
\hline No (BMI < 30) & $169(69.8 \%)$ & $103(72.0 \%)$ & $66(66.7 \%)$ & \\
\hline Yes $(B M I \geq 30)$ & $73(30.2 \%)$ & $40(28.0 \%)$ & $33(33.3 \%)$ & 0.453 \\
\hline
\end{tabular}

Quantitative variables are expressed as mean \pm standard deviation. Qualitative variables are expressed as percentages of total. The body mass index (BMI) was evaluated in only 242 patients (68\%); AMI - acute myocardial infarction

Table 3. Genotype and allele polymorphism frequencies in the series.

\begin{tabular}{|c|c|c|c|c|c|}
\hline \multirow{2}{*}{$\begin{array}{l}\text { Polymorphisms } \\
\text { ACE }\end{array}$} & \multicolumn{3}{|c|}{$\begin{array}{l}\text { Genotype frequencies } \\
\text { Number of cases }(\%)\end{array}$} & \multicolumn{2}{|c|}{ Allele frequencies (\%) } \\
\hline & II & ID & DD & 1 & D \\
\hline & $57(16.0)$ & $171(48.0)$ & $128(36.0)$ & 40.0 & 60.0 \\
\hline \multirow[t]{2}{*}{ AT1R } & $A A$ & $A C$ & $\mathrm{CC}$ & $A$ & $\mathrm{C}$ \\
\hline & $189(53.1)$ & $147(41.3)$ & $20(5.6)$ & 73.7 & 26.3 \\
\hline \multirow[t]{2}{*}{ PAI-I } & $4 \mathrm{G} / 4 \mathrm{G}$ & $4 \mathrm{G} / 5 \mathrm{G}$ & $5 \mathrm{G} / 5 \mathrm{G}$ & $4 \mathrm{G}$ & $5 G$ \\
\hline & $91(25.6)$ & $182(51.1)$ & 83 (23.3) & 51.1 & 48.9 \\
\hline \multirow[t]{2}{*}{ GPIIla } & a1a1 & a1a2 & $\mathrm{a} 2 \mathrm{a} 2$ & a1 & a2 \\
\hline & $233(65.4)$ & $112(31.5)$ & $11(3.1)$ & 81.2 & 18.8 \\
\hline
\end{tabular}

Qualitative variables are expressed as percentages of total; ACE — angiotensin-I converting enzyme; AT1R - angiotensin II type 1 receptor; PAI-1 — plasminogen activator inhibitor; GPIIla - platelet glycoprotein IIla

morbi-mortality in the industrialized countries, due to a higher life expectancy and an inadequate diet habit and life style. Predisposing factors such as age, gender, BMI, hypertension, hypercholesterolemia, diabetes mellitus, smoking or a family history of cardiovascular disease are well known, however, they only explain half of the cases of coronary ischemic events. Therefore, new etiology factors in the genetic field are being investigated and many polymorphisms are being implicated in the physiopathology of the coronary events.

Cambien et al. [12] first demonstrated a possible role of the ACE DD genotype as a cardiovascular risk factor. However, in subsequent years different studies have reached conflicting 
Table 4. Clinical, echocardiographic and angiographic data from the whole series.

\begin{tabular}{|c|c|}
\hline Parameters & Patients (\%) \\
\hline \multicolumn{2}{|l|}{ Infarction location: } \\
\hline Anterior & $115(32.3 \%)$ \\
\hline Inferior & $153(43.0 \%)$ \\
\hline Posterior & $30(8.4 \%)$ \\
\hline Non $\mathrm{Q}$ wave & $41(11.5 \%)$ \\
\hline Other locations & $17(4.8 \%)$ \\
\hline \multicolumn{2}{|l|}{ Fibrinolysis: } \\
\hline No & $196(55.1 \%)$ \\
\hline Yes & $160(44.9 \%)$ \\
\hline \multicolumn{2}{|l|}{ LVEF: } \\
\hline$<40 \%$ & $71(20.0 \%)$ \\
\hline$\geq 40 \%$ & $285(80.0 \%)$ \\
\hline \multicolumn{2}{|c|}{ Coronary arteries affected: } \\
\hline None & $24(10.8 \%)$ \\
\hline One & $106(47.5 \%)$ \\
\hline Two & $53(23.8 \%)$ \\
\hline Three & $40(17.9 \%)$ \\
\hline \multicolumn{2}{|c|}{ Coronarography severity: } \\
\hline None significant & $40(17.9 \%)$ \\
\hline Moderate & $23(10.3 \%)$ \\
\hline Severe & $125(56.1 \%)$ \\
\hline Diffuse & $10(4.5 \%)$ \\
\hline Severe and diffuse & $7(3.1 \%)$ \\
\hline Total occlusion & $18(8.1 \%)$ \\
\hline \multicolumn{2}{|l|}{ Revascularization: } \\
\hline No & $111(49.8 \%)$ \\
\hline Yes* & $112(50.2 \%)$ \\
\hline
\end{tabular}

Qualitative variables are expressed as percentages of total. Of the 356 patients enrolled in the study, $223(62.6 \%)$ underwent catheterization, either during hospitalization or soon after hospital discharge. *Both percutaneous and surgical revascularization; LVEF — left ventricular ejection fraction

results. In this context, and as cornerstone in the literature reporting on the ACE ID polymorphism, Agerholm-Larsen et al. [13] demonstrated, in a meta-analyses of small and large studies that included a total of 32.715 white individuals, that plasma ACE activity was significantly increased for ACE ID and DD versus II patients, that blood pressure was not influenced by genotype, and that the risk of $\mathrm{MI}$ and ischemic heart disease was increased by $47 \%$ and $29 \%$, respectively, for DD vs. ID and II genotypes in small studies but not in large researches. However, it should be emphasized that many patients included in the meta-analyses were under ACE-inhibitors or sartans which may have changed the results.

In relation to the clinical outcome after first MI, Ludwig et al. [14] showed (in patients who had
Table 5. Cox univariate analysis of the variables that influenced the clinical outcome.

\begin{tabular}{|c|c|c|}
\hline Variable & $\begin{array}{l}\text { Relative risk } \\
\text { ( } \pm 95 \% \mathrm{CI})\end{array}$ & $\mathbf{P}$ \\
\hline Age at infarction & $1.021(1.007-1.036)$ & 0.004 \\
\hline \multicolumn{3}{|l|}{ Age at infarction: } \\
\hline Early infarction & 1.000 & \\
\hline Late infarction & $1.576(1.073-2.315)$ & 0.020 \\
\hline \multicolumn{3}{|l|}{ Family history: } \\
\hline No & 1.000 & \\
\hline Yes & 1.859 (1.189-2.906) & 0.007 \\
\hline \multicolumn{3}{|l|}{ Diabetes mellitus: } \\
\hline No & 1.000 & \\
\hline Yes & $1.758(1.201-2.574)$ & 0.004 \\
\hline \multicolumn{3}{|l|}{ Arterial hypertension: } \\
\hline No & 1.000 & \\
\hline Yes & $1.417(0.965-2.080)$ & 0.076 \\
\hline \multicolumn{3}{|l|}{ Fibrinolysis: } \\
\hline No & 1.000 & \\
\hline Yes & $0.599(0.401-0.893)$ & 0.012 \\
\hline \multicolumn{3}{|l|}{ ACE genotype: } \\
\hline No-DD & 1.000 & \\
\hline DD & $1.419(0.966-2.084)$ & 0.074 \\
\hline \multicolumn{3}{|l|}{ Persistence of smoking: } \\
\hline No & 1.000 & \\
\hline Yes & $2.051(1.099-3.825)$ & 0.024 \\
\hline \multicolumn{3}{|l|}{ Coronary artery disease: } \\
\hline None or one vessels & 1.000 & \\
\hline Two or three vessels & 1.618 (1.009-2.596) & 0.046 \\
\hline
\end{tabular}

ACE - angiotensin-I converting enzyme; $\mathrm{Cl}$ - confidence intervals

undergone coronary angiography either because of symptoms relating to CAD or unrelated conditions such as valvular disease) that the ACE D allele was associated with a greater risk of MI but not with the development of atherosclerosis. Likewise, Yoshida et al. [15], in a retrospectively study of 176 patients, suggested that the presence of the deletion allele of the ACE gene could be a risk factor for secondary cardiac events after MI. Also, Palmer et al. [16], in 978 patients with MI and a mean age of 62.1 years, showed a strong association between the $\mathrm{D}$ allele and mortality over a mean of 2.6 years of follow-up. There were similar results in our series where the DD genotype led to a 1.5 increased risk of having an unfavorable outcome when compared with No-DD patients but without having a significant association with coronary angiographic data. This may suggest, as stated by Ludwig et al. [14], that the risk of MI is influenced by 2 independent processes: atherogenesis that leads to coronary stenosis and the RAAS that appears to confer significant risk of 
Table 6. Cox proportional hazards to assess the effect of multiple covariates on survival.

\begin{tabular}{lcccc}
\hline Parameters & Sig. & Relative risk & \multicolumn{2}{c}{ 95\% confidence interval } \\
\cline { 3 - 5 } & & & \multicolumn{2}{c}{ Inferior } \\
Age & & 1.018 & 1.002 & 1.033 \\
Family history (yes vs. no) & 0.023 & 1.747 & 1.110 & 2.752 \\
Diabetes mellitus (yes vs. no) & 0.016 & 1.465 & 0.984 & 2.180 \\
ACE (DD vs. No-DD) & 0.060 & 1.561 & 1.048 & 2.326 \\
ACE-AT1R (DD/No-AA vs. rest) & 0.028 & 1.960 & 1.230 & 3.123 \\
ACE-GPIIla (DD/No-a1a1 vs. rest) & 0.005 & 2.086 & 1.248 & 3.487 \\
Patients with DD plus 1 or 2 unfavorable & 0.005 & 1.978 & 1.286 & 3.043 \\
genotypes vs. the rest of the patients & 0.002 & & & \\
\hline
\end{tabular}

ACE — angiotensin-I converting enzyme; AT1R — angiotensin II type 1 receptor; GPIIla — platelet glycoprotein IIla; Sig. — significant

infarction by influencing the conversion to MI by rupture of the plaque surface.

However, the evidence is controversial and some authors have found no association between ACE I/D polymorphism and the increased risk of coronary events after first MI [17-19]. This may be due to the fact that, in the case of Franco et al. [17] the study population was under 45 years old, in the case of Andrikopoulos et al. [18] only in-hospital mortality was studied, and in the case of Keavney et al. [19] the only patients enrolled, who were subjected to fibrinolysis, had documented MI. Also, Arca et al. [20] in 394 consecutive patients who underwent coronary angiography of whom $21.5 \%$ had a history of MI, did not provide evidence of a significant association between the $\mathrm{ACE}$ genotypes and the conversion of coronary stenosis to MI. As well, Hanon et al. [21], in 1039 consecutive white patients with symptomatic CAD who had successful percutaneous coronary intervention with stent implantation, found that the ACE I/D polymorphism did not influence the long term prognosis of these patients.

On the contrary, Tokunaga et al. [22], in a selected cohort of 441 Japanese patients with first $\mathrm{MI}$, found an inverse relationship between the ACE DD genotype and the incidence of a new coronary event being the DD genotype associated with a significantly lower cardiac mortality. However, in this study the percentage of patients with the DD genotype was much lower than in our series and the follow-up period was considerably shorter.

Regarding the synergistic effect, between the ACE I/D and the AT1R A1166C polymorphisms, different studies have shown conflicting results. In this context, some authors [23-25] have found that subjects carrying the D allele of ACE gene and the $\mathrm{C}$ allele of AT1R gene had a higher risk of MI than those patients with the AT1R AA and the ACE II combined genotype. However, other authors have not found such synergic effect between both polymorphisms [26, 27].

In relation whether the above-mentioned polymorphisms are associated with an increased risk of MACE following an acute MI, Andrikopoulos et al. [18], in a multicenter and prospective study of 1,603 consecutive patients with MI, showed and argued against a measurable effect of the ACE gene I/D polymorphism and A1166C polymorphism of the ATR1 gene on early prognosis after MI. However, these findings could be in relation to the low frequency of the $\mathrm{C}$ allele of AT1R genotype seen in their series.

In relation to the rest of polymorphisms, Margaglione et al. [28] in a cohort of 1,179 healthy employees found that the $4 \mathrm{G} / 4 \mathrm{G}$ carriers exhibited a more frequent family history of $\mathrm{CAD}$, supporting the hypothesis that the $4 \mathrm{G}$ variant was a transmissible coronary risk factor. However, Panahloo et al. [29] found no evidence that subjects with the $4 \mathrm{G} / 4 \mathrm{G}$ polymorphism had higher PAI-1 levels on admission or 6 months after MI. Meanwhile, Bray et al. [30] showed that the GPIIIa a1/a2 genotype was associated with an excess of recurrent coronary events in patients after MI who did not receive statins and that the ACE DD genotype added to this risk. Similarly, in our series, those patients with the ACE DD genotype and at least one or two theoretically unfavorable genotypes, the AT1R No-AA, the GPIIIa No-ala1 or the combination of both, double the risk of MACE in the follow up of $25 \%$ of our patients.

\section{Limitations of the study}

The limitations of our study are the lack of data on $\mathrm{ACE}$ and angiotensin II activity and the una- 
wareness if the patient was under ACE-inhibitors or sartans at hospital discharge which might have enabled us to establish stronger correlations of the studied genotypes with the clinical outcome. Also the recruitment of patients with MI at discharge may have led to a selection bias since highest-risk patients that had died during hospital stay were not included in the study.

\section{Conclusions}

We can conclude that the pathogenesis of $\mathrm{MI}$ is complex because the genetic risk profile is heterogeneous, due to the involvement of many low-penetrant candidate genes, and because environmental and cardiovascular risk factors may influence the prognosis. However, screening patients for the studied polymorphisms may be useful for a secondary prevention strategy due to the known implication of RAAS, anticoagulation and platelet anti-aggregation therapy in the relapse of new coronary events.

\section{Conflict of interest: none declared}

\section{References}

1. CARDIoGRAMplusC4D Consortium, Deloukas P, Kanoni S, Willenborg $\mathrm{C}$ et al. Large-scale association analysis identifies new risk loci for coronary artery disease. Nat Genet, 2013; 45: 25-33.

2. Kushner FG, Hand M, Smith SC Jr et al. 2009 focused updates: ACC/AHA guidelines for the management of patients with ST-elevation myocardial infarction (updating the 2004 guideline and 2007 focused update) and ACC/AHA/SCAI guidelines on percutaneous coronary intervention (updating the 2005 guideline and 2007 focused update) a report of the American College of Cardiology Foundation/American Heart Association Task Force on Practice Guidelines. J Am Coll Cardiol, 2009; 54: 2205-2241.

3. Anderson JL, Adams CD, Antman EM et al. ACC/AHA 2007 guidelines for the management of patients with unstable angina/ /non ST-elevation myocardial infarction: a report of the American College of Cardiology/American Heart Association Task Force on Practice Guidelines (Writing Committee to Revise the $2002 \mathrm{Gu}$ idelines for the Management of Patients With Unstable Angina/ /Non ST-Elevation Myocardial Infarction): developed in collaboration with the American College of Emergency Physicians, the Society for Cardiovascular Angiography and Interventions, and the Society of Thoracic Surgeons: Endorsed by the American Association of Cardiovascular and Pulmonary Rehabilitation and the Society for Academic Emergency Medicine. Circulation, 2007; 116: e148-e304.

4. Rigat B, Hubert C, Alhenc-Gelas F et al. An insertion/deletion polymorphism in the angiotensin I-converting enzyme gene accounting for half the variance of serum enzyme levels. J Clin Invest, 1990; 86: 1343-1346.

5. Rigat B, Hubert C, Corvol P et al. PCR detection of the insertion/ /deletion polymorphism of the human angiotensin converting enzyme gene (DCP1) (dipeptidyl carboxypeptidase 1). Nucleic Acids Res, 1992; 20: 1433.

6. Maitland-van der Zee AH, van Wieren-de Wijer DB, de Boer A et al. Genetic variation in the renin-angiotensin system, use of renin-angiotensin system inhibitors and the risk of myocardial infarction. J Renin Angiotensin Aldosterone Syst, 2011; 12: 208-214.

7. Berge KE, Bakken A, Bøhn M et al. A DNA polymorphism at the angiotensin II type 1 receptor (AT1R) locus and myocardial infarction. Clin Genet, 1997; 52: 71-76.

8. Hoekstra T, Geleijnse JM, Schouten EG et al. Plasminogen activator inhibitor-type 1: Its plasma determinants and relation with cardiovascular risk. Thromb Haemost, 2004; 91: 861-862.

9. Margaglione M, Grandone E, Cappucci $\mathrm{G}$ et al. An alternative method for PAI-1 promoter polymorphism $(4 \mathrm{G} / 5 \mathrm{G})$ typing. Thromb Haemost, 1997; 77: 605-606.

10. Reiner A, Siscovick DS, Rosendaal FR. Platelet glycoprotein polymorphisms and risk of thrombosis: facts and fancies. Rev Clin Exp Hematol, 2001; 5: 262-287.

11. Ridker PM, Hennekens $\mathrm{CH}$, Schmitz $\mathrm{C}$ et al. PIA1/A2 polymorphism of platelet glycoprotein IIIa and risks of myocardial infarction, stroke, and venous thrombosis. Lancet, 1997; 349: 385-388.

12. Cambien F, Poirier O, Lecerf L et al. Deletion polymorphism in the gene for angiotensin-converting enzyme is a potent risk factor for myocardial infarction. Nature, 1992; 359: 641-644.

13. Agerholm-Larsen B, Nordestgaard BG, Tybjaerg-Hansen A. ACE gene polymorphism in cardiovascular disease: Meta-analyses of small and large studies in whites. Arterioscler Thromb Vasc Biol, 2000; 20: 484-492.

14. Ludwig E, Corneli PS, Anderson JL et al. Angiotensin-converting enzyme gene polymorphism is associated with myocardial infarction but not with development of coronary stenosis. Circulation, 1995; 91: 2120-2124.

15. Yoshida M, Iwai N, Ohmichi N et al. D allele of the angiotensin-converting enzyme gene is a risk factor for secondary cardiac events after myocardial infarction. Int J Cardiol, 1999; 70: 119-125.

16. Palmer BR, Pilbrow AP, Yandle TG et al. Angiotensin-converting enzyme gene polymorphism interacts with left ventricular ejection fraction and brain natriuretic peptide levels to predict mortality after myocardial infarction. J Am Coll Cardiol, 2003; 41: 729-736.

17. Franco E, Palumbo L, Crobu F et al. Renin-angiotensin-aldosterone system polymorphisms: A role or a hole in occurrence and long-term prognosis of acute myocardial infarction at young age. BMC Med Genet, 2007; 8: 27.

18. Andrikopoulos GK, Tzeis SM, Needham EW et al. GEMIG study investigators. Lack of association between common polymorphisms in genes of the renin-angiotensin system and mortality after myocardial infarction. Cardiology, 2005; 103: 185-188.

19. Keavney B, McKenzie C, Parish S et al. Large-scale test of hypothesised associations between the angiotensin-converting-enzyme insertion/deletion polymorphism and myocardial infarction in about 5,000 cases and 6,000 controls. International Studies of Infarct Survival (ISIS) Collaborators. Lancet, 2000; 355: 434-442.

20. Arca M, Pannitteri G, Campagna F et al. Angiotensin-converting enzyme gene polymorphism is not associated with coronary atherosclerosis and myocardial infarction in a sample of Italian patients. Eur J Clin Invest, 1998; 28: 485-490. 
21. Hamon M, Fradin S, Denizet A et al. Prospective evaluation of the effect of an angiotensin I converting enzyme gene polymorphism on the long term risk of major adverse cardiac events after percutaneous coronary intervention. Heart, 2003; 89: 321-325.

22. Tokunaga S, Tsuji $\mathrm{H}$, Nishiue $\mathrm{T}$ et al. Lower mortality in patients with the DD genotype of the angiotensin-converting enzyme gene after acute myocardial infarction. Acta Cardiol, 2001; 56: 351-355.

23. Kaur R, Das R, Ahluwalia J et al. Synergistic effect of angiotensin II type-1 receptor 1166A/C with angiotensin-converting enzyme polymorphism on risk of acute myocardial infarction in north Indians. J Renin Angiotensin Aldosterone Syst, 2012; 13: 440-445.

24. Tiret L, Bonnardeaux A, Poirier O et al. Synergistic effects of angiotensin-converting enzyme and angiotensin-II type 1 receptor gene polymorphisms on risk of myocardial infarction. Lancet, 1994; 344: 910-913.

25. Araújo MA, Goulart LR, Cordeiro ER et al. Genotypic interactions of renin-angiotensin system genes in myocardial infarction. Int J Cardiol, 2005; 103: 27-32.

26. Gardemann A, Nguyen QD, Humme J et al. Angiotensin II type 1 receptor $\mathrm{A} 1166 \mathrm{C}$ gene polymorphism. Absence of an association with the risk of coronary artery disease and myocardial infarction and of a synergistic effect with angiotensin-converting enzyme gene polymorphism on the risk of these diseases. Eur Heart J, 1998; 19: 1657-1665.

27. Nakauchi Y, Suehiro T, Yamamoto M et al. Significance of angiotensin I-converting enzyme and angiotensin II type 1 receptor gene polymorphisms as risk factors for coronary heart disease. Atherosclerosis, 1996; 125: 161-169.

28. Margaglione M, Cappucci G, Colaizzo D et al. The PAI-1 gene locus $4 \mathrm{G} / 5 \mathrm{G}$ polymorphism is associated with a family history of coronary artery disease. Arterioscler Thromb Vasc Biol, 1998; 18: 152-156.

29. Panahloo A, Mohamed-Ali V, Gray RP et al. Plasminogen activator inhibitor-1 (PAI-1) activity post myocardial infarction: the role of acute phase reactants, insulin-like molecules and promoter $(4 \mathrm{G} / 5 \mathrm{G})$ polymorphism in the PAI-1 gene. Atherosclerosis, 2003; 168: 297-304.

30. Bray PF, Cannon CP, Goldschmidt-Clermont P et al. The platelet $\mathrm{Pl}(\mathrm{A} 2)$ and angiotensin-converting enzyme (ACE) D allele polymorphisms and the risk of recurrent events after acute myocardial infarction. Am J Cardiol, 2001; 88: 347-352. 